\title{
Reference conditions for restoration of heterogeneous \\ Mediterranean wetland are best defined by multiple, hydrologically diverse sites
}

Running head: Reference conditions for Mediterranean wetland

Alberto Vélez-Martín, ${ }^{1,2}$ Anthony J. Davy, ${ }^{3}$ Carlos J. Luque, ${ }^{1}$ and Eloy M.

Castellanos $^{1}$

${ }^{1}$ Área de Ecología/RNM 311 Ecología y Medio Ambiente, Departamento de Ciencias Integradas, Facultad de Ciencias Experimentales, Universidad de Huelva, Campus de Excelencia Internacional del Mar CEIMAR y Campus de Excelencia Internacional CEICAMBIO, 21071-Huelva, Spain

${ }^{2}$ Address correspondence to A. Vélez-Martín, email: alberto.velez@dbasp.uhu.es

${ }^{3}$ Centre for Ecology, Evolution and Conservation, School of Biological Sciences, University of East Anglia, Norwich Research Park, Norwich, NR4 7TJ, UK

Authors contributions: AVM, AD, CL, EC conceived and designed the research; $A V M, A D, C L$, EC carried out the field work; AVM, AD, CL, EC analyzed the data; AVM, AD, CL, EC wrote and edited the manuscript.

Accepted for publication in Restoration Ecology (ISSN: 1526-100X), 8 May 2017 


\section{Abstract}

In a mediterranean climate, the vegetation of embanked salt marshes can vary considerably in time and space to obscure the definition of reference condition for restoration purposes. The aim of our study was to find a basis for defining reference vegetation for the reinstatement of a wetland hydrological regime on abandoned agricultural land. We investigated five reference sites surrounding a 2,668 ha restoration site in the Doñana National Park (southwest Spain). Environmental conditions were monitored on a sampling grid for seven years: surface elevation and hydroperiod were mapped (using LIDAR -Light Detection and Ranging- and satellite imagery, respectively) and rainfall, soil salinity and soil $\mathrm{pH}$ were recorded. The reference sites collectively encompassed the range of elevation and environmental conditions at the restoration site, although none individually was representative. The vegetation at the reference sites was sampled annually at fixed grid points. Hierarchical cluster analyses identified assemblages of perennial and annual species that were differently distributed among the reference sites. BIO-ENV analysis showed that the distribution of perennial assemblages was determined by elevation, annual hydroperiod, and salinity. More labile annual assemblages were loosely associated with particular perennial ones. Species composition fluctuated over the seven years, in concert with rainfall and hydroperiod, but showed no directional change. Understanding the hydro-chemical drivers of spatio-temporal variation in vegetation across multiple sites has established a rationale for defining reference conditions for large, heterogeneous wetland restoration sites.

Key words: Elevation; Hydroperiod; Long-term monitoring; Mediterranean climate; Multiple reference sites; Non-tidal salt marshes.

\section{Implications for practice:}


- Restoration targets based on a single year or single reference site would not capture complex vegetational heterogeneity.

- Systematically sampling multiple reference sites that collectively encompass the spatiotemporal environmental heterogeneity of the restoration site allowed identification of the underlying hydrological drivers of vegetation structure.

- Variations in the timing and distribution of flooding modulate plant distribution across the elevational mosaic and define the boundaries of a dynamic envelope of reference states.

- Such a hydrologically-based approach should be broadly applicable to complex wetlands. 


\section{Introduction}

Defining an undamaged or reference condition is fundamental to ecological restoration, as it informs the design of restoration programmes, goal-setting and assessment of eventual success (Clewell \& Aronson 2007). Historical conditions are seldom known adequately (Balaguer et al. 2014) and the usual alternative is to study undamaged reference sites that are analogues of a site to be restored (e.g. Onaindia et al. 2001; Garbutt \& Wolters 2008; Mossman et al. 2012a; Van Loon-Steensma et al. 2015). Furthermore, spatially heterogeneous landscapes, unfortunately, may obscure the identification of a good match, and reference sites may themselves change with time, either successionally or through random fluctuation (White \& Walker 1997). The design of large-scale, heterogeneous wetland restorations is inevitably complex (Hughes et al. 2011), but analysis of the underlying drivers of spatial and temporal variation should aid the identification of good matches and facilitate the use of multiple reference sites (White \& Walker 1997; Weinstein et al. 2001). In theory, reference and restoration wetland sites would be expected to share the same hydrochemical determinants of spatio-temporal heterogeneity, (Weishar et al. 2005) but, in practice, further investigations should be carried out in order to check this presumption.

Little is known about the restoration of coastal salt marshes that lack the short-term pulse-stabilization of tidal inundation, and whose hydrology is therefore dominated by the erratic winter rainfall and strongly seasonal evapotranspiration characteristic of the Mediterranean region (Mitsch \& Gosselink 1993). Short-term studies do not allow us to account for the effects of such temporal variation, or even those of possible successional change, which are superimposed on differences in surface elevation creating hydrological heterogeneity at a range of scales. Therefore, longer and continuous studies are needed to understand whether these drivers of vegetational heterogeneity could define a mosaic of reference states for wetlands. The extensive wetlands of the Doñana National Park (southwest 
Spain) exemplify these restoration problems well. They are formed over clay basins, so rainfall during the wet season causes floods and surface run-off, but evapotranspiration during the dry season leaves the soils dry and cracked until the next wet season. Harbouring unique biodiversity, they have been designated a World Heritage Site, a Biosphere Reserve and a Ramsar site (García-Novo \& Marín 2006). However, large areas were drained for the production of forage and wheat crops in the 1970s. More recently, agricultural use has ceased and a more natural flooding regime has been reinstated as part of the integrated water regeneration scheme of the Guadalquivir Marshes (Saura et al. 2001). Within this area, 2,668 ha have been designated for eventual restoration to wetland. Several surrounding saltmarshes had escaped conversion to agriculture and were candidates to be reference sites. Their vegetation consisted of a relatively stable matrix of a few perennial halophytic species, interspersed with many annuals whose relative abundance could vary more locally and from year-to-year. It was not known to what extent these sites, separately or collectively, could represent the restoration potential of Guadalquivir Marshes.

Our aim was to examine multiple reference sites and to establish an approach for the definition of reference conditions in changing, heterogeneous wetland landscapes. The approach was to examine the relationships between their plant communities and surface hydrology/hydrochemistry over a seven-year period that encompassed a range of annual and seasonal fluctuations in rainfall. Specific objectives were: (1) to characterize spatial variation in surface elevation, and inter-annual changes in flooding regime and salinity at the reference sites; (2) to examine spatial distribution and inter-annual variation in the composition of the plant communities at reference sites; (3) to compare changes in the flooding and salinity regimes at the restoration site with those at reference sites; and (4) to assess the extent to which the reference sites, singly or in combination, potentially define dynamic ranges of reference state for the restoration of a mosaic of coastal wetland vegetation. 


\section{Methods}

\section{Study sites}

\section{Doñana marshlands}

The marshlands of the Doñana National Park occupy 25,000 ha in the south of the Guadalquivir estuary (Fig. S1), originally functioning as its floodplain. Embankment for agricultural land-reclamation in the 20th century virtually removed tidal influence and the capacity for flood-water storage, leaving rainfall as the principal water source that determines flooding pattern throughout most of the Doñana marshes (Díaz-Delgado et al. 2006). The Mediterranean climate has reliably hot summers with virtually no rainfall but the remainder of the year is temperate with variable rainfall (average annual rainfall $552 \mathrm{~mm}$; average annual temperature is $17^{\circ} \mathrm{C}$ ). Although isolated from tidal influence, the marshes remain brackish to saline as a result of seawater intrusion and high evapotranspiration. The largely halophytic vegetation comprises three components: a matrix of perennial, woody species (mainly Amaranthaceae); numerous annual, herbaceous species, dependent on a seed bank and submerged aquatic macrophytes in flooded areas (Rivas-Martínez et al. 1980; Marañón et al. 1989; García et al. 1993; Espinar 2009).

\section{The restoration site}

Caracoles Estate is situated at the northeast boundary of the Doñana National Park (Fig. S1). It was part of the floodplain of the Caño Travieso (hereafter, Travieso), a stream connected to the Guadiamar River, itself a tributary of the Guadalquivir. In the early 1970s, 2,668 ha had been reclaimed for cultivation by the construction of perimeter embankments, excavation of a drainage system and blocking the Travieso stream, which had previously supplied large amounts of water to the marsh. In 2004, work began to reinstate the original 
water-supply regime, by damming the drainage ditches, partially removing the perimeter embankments (see Fig. S1) and re-excavating the original course of the Travieso to a depth of c. $7 \mathrm{~cm}$ below previous elevation. The restoration sites thus comprise Caracoles (main area) and Travieso.

\section{Reference sites}

Five candidate reference sites surround the restoration site (Fig. S1): Lucio del Cangrejo y Marilópez (hereafter, Cangrejo), circa 1,200 ha; Reserva Biológica del Guadiamar (hereafter, Reserva Guadiamar), 1,300 ha; Entremuros, 500 ha; Huerta Tejada, 50 ha; and El Matochal (hereafter, Matochal), 530 ha. After the restoration works, only Cangrejo and Reserva Guadiamar will be directly connected to the restoration area, as the other sites are still separated from it by embankments. Huerta Tejada had been partially drained for land reclamation but has never been cultivated. Entremuros is a 1-km wide strip, along which the Travieso had been channelled to prevent it flooding Caracoles Estate during the agricultural era.

\section{Plant and soil measurements}

A grid of permanent sampling points along transects that spanned both the restoration and the reference sites was established in 2004. They were aggregated in linear groups of nine sampling points at Caracoles Estate but the same pattern was projected into the reference sites (Fig. S1). Sampling points were spaced at least $62.5 \mathrm{~m}$ apart from each other, representing each site approximately in proportion to its area and elevational range. The distribution of 441 sampling points was: 270 in Caracoles Estate (including 57 in the reexcavated channel of the Travieso) and 171 in the reference sites (45 in Cangrejo, 54 in Reserva Guadiamar, 45 in Entremuros, 18 in Huerta Tejada and nine in Matochal). 
At each sampling point in the five reference sites we placed two replicate $2 \times 2-m$ permanent quadrats (one exactly at the point and the other $10 \mathrm{~m}$ east of it). We recorded the cover percentage of plant species and bare ground using a six-point Braun-Blanquet coverabundance scale $(<1,1-5,5-25,25-50,50-75$ and $75-100 \%$ cover $)$. Mean scores for the class means of the two quadrats were used in statistical analyses. Recording was carried out annually from 2004 to 2010 during the dry season (June-July). This was at the end of the growing season when cover was highest, most species were represented, conditions were most comparable from year to year, and accessibility was optimal. However, only a third of the points (144) was sampled in 2004, and Matochal was sampled for the first time in 2006. Hence a total of 1,071 vegetation samples over the seven years was analyzed.

Soil samples were taken from the central point of each aggregate of nine grid points (Fig. S1) annually in the dry season from 2004-2010, except 2005. Matochal was sampled only from 2008-2010. This yielded a total of 130 samples from Caracoles Estate and 101 samples from reference sites, from each depth. Three replicate subsamples of c. $100 \mathrm{ml}$ soil (c. $1 \mathrm{~m}$ apart, immediately outside the vegetation quadrats) were taken from surface $(0-2 \mathrm{~cm})$ and subsurface (8-10 $\mathrm{cm}$ deep) layers. Soil was air-dried under laboratory conditions, crushed and sieved to less than $2 \mathrm{~mm}$. Electrical conductivity (E.C.) and $\mathrm{pH}$ were measured in 1:1 (by volume) soil-water mixtures after equilibration over-night.

\section{Elevation, inundation and rainfall}

Surface elevation for each sampling point in both Caracoles (main area) and the five reference sites was obtained from LIDAR (Light Detection and Ranging) data (precision $>0.5$ $\mathrm{m}$ horizontally and $>0.15 \mathrm{~m}$ vertically). The flight was commissioned by the Confederación Hidrográfica del Guadalquivir in September 2002 for the whole Doñana marsh. This was when the terrain was dry, with no standing water; errors due to vegetation were minimized by 
the large fraction of bare ground (37.2\%) and sparse vegetation. A raster file with a pixel size of $2 \mathrm{~m} \times 2 \mathrm{~m}$, provided by the Estación Biológica de Doñana, was processed using ArcGis 10.0 (ESRI ${ }^{\circledR}$ ArcMap $\left.^{\mathrm{TM}} 10.0\right)$. LiDAR data were ground-truthed at numerous permanent sampling points using a high-resolution $( \pm 2 \mathrm{~cm})$ differential GPS (Leica 1200). After topsoil removal at Travieso in 2004, the new elevation was measured at each permanent sampling point using the differential GPS.

The extent and duration of surface flooding were determined from examination of successive false-colour images (250-m pixel size) from MODIS (Moderate Resolution Imaging Spectroradiometer, aboard Aqua (EOS PM) satellites). These were compared with LANDSAT imagery from a narrower span of dates but with a higher precision (30-m pixel size) from the Landsat images online server (LAST-EBD, CSIC). False colour compositions of both datasets indicated flooded areas. Inundated areas were ground-truthed by field observation. For each grid point, the annual period of inundation (hydroperiod) and the periods of inundation during autumn (September-November), winter (December-February), spring (March-May) and summer (June-August) were estimated, assuming that inundation was continuous between consecutive images (Díaz-Delgado et al. 2010).

Annual and seasonal rainfall data for 2004-2010 were obtained from the Palacio de Doñana Weather Station (lat $36^{\circ} 59^{`} \mathrm{~N}$, long $6^{\circ} 26^{`} \mathrm{~W}$ ), approximately $14 \mathrm{~km}$ southwest of the centre of Caracoles Estate.

\section{Data analysis}

The vegetation of the study sites was characterized by a structural matrix of a few perennial, mostly shrubby halophytes, with a large number of annual or ephemeral species occupying the interstices. Hierarchical cluster analysis of all species yielded a complex range of communities whose environmental determinants were substantially obscured, probably by 
the diversity and variability in distribution of the short-lived species. Consequently, cluster analyses were carried out separately for perennial and annual species to define communities of each present across all the reference sites (Vegan 2.0-4 within 'R'; R Core Team 2013). Bray-Curtis similarity matrices were calculated from $\log (x+1)$-transformed species abundance data, using all the points sampled over seven years, in all five reference sites $(\mathrm{n}=$ $1,071)$.

The taxonomic composition and species abundance of the resulting plant communities were examined by a permutation-based test with a nonparametric one-way analysis of similarity (ANOSIM) to detect significant differences between communities. The relative contribution of each species to site dissimilarities was quantified using similarity percentages analysis (SIMPER), with a cut-off criterion of $90 \%$, to identify subsets of the most important species (Clarke \& Warwick 1994). This was to identify those species that characterize each group and those responsible for discriminating between them. PAST 2.14 (Hammer et al. 2001) was used for these analyses.

Changes in vegetation from year to year over the seven years were visualised using non-metric multidimensional scaling (NMDS) ordination plots of the perennial and annual species separately, using ' $R$ '. Transition matrices, representing the probability of a species assemblage in one year being replaced by another the following year, were also computed separately for the perennial and annual assemblages.

The statistical significance of differences in environmental factors between sites and among perennial assemblages was determined using one-way ANOVA or Kruskal-Wallis tests, depending on whether assumptions of normality and homoscedasticity were fulfilled (SPSS 21.0: IBM Corporation 2012). When significant differences were detected, Tukey or Mann-Whitney post-hoc comparisons were performed, as appropriate. Inter-annual 
differences in environmental factors were tested with repeated measures ANOVA or a Friedman test. When tests were significant, post-hoc pairwise comparisons were made.

Associations between annual and perennial communities were analysed using a contingency table and a chi-square test. The overall relationships between community structure and the environmental variables were examined with the BIO-ENV analytical procedure of Clarke and Ainsworth (1993), which estimates independent effects where there are multiple collinear relationships. Analyses were carried out separately for perennial and annual species with 15 environmental variables (elevation, surface E.C., subsurface E.C., surface $\mathrm{pH}$, subsurface $\mathrm{pH}$, annual rainfall, autumn, winter, spring and summer rainfalls, annual hydroperiod, and autumn, winter, spring and summer hydroperiods). The procedure gives a correlation coefficient for the dissimilarities between species and the subset of environmental variables whose dissimilarities are best correlated with the species dissimilarities. A Bray-Curtis dissimilarity matrix was used for species and a normalized Euclidean distance matrix for environmental variables. The significance of correlations was determined by Mantel tests. Analyses were carried out using the Vegan package within ' $R$ '.

\section{Results}

\section{Abiotic environment}

\section{Surface elevation}

The range of surface elevation after completion of ground works at the restoration site varied by more than $1.1 \mathrm{~m}$; unsurprisingly, the main area of Caracoles was generally at higher elevation than the re-excavated Travieso (Fig. S2). Among the references sites, Cangrejo and Reserva Guadiamar had low elevational ranges similar to that of Travieso. Matochal and Huerta Tejada occupied the middle to upper ranges, whereas Entremuros showed the widest range, although over a small area (Fig. S2). Thus, none of the reference sites individually 
represented the full elevational range of the restoration site but collectively they were representative.

\section{Hydrology and hydrochemistry}

There were consistent differences both between the sites and also from year to year in mean salinity (expressed as E.C.) and annual hydroperiod (Fig. 1). Surface salinity was greater in the surface soil than in the deeper samples (Friedman; $\chi^{2}=9.51, p<0.01$ ), and three of the reference sites (Cangrejo, Entremuros and Reserva Guadiamar) were consistently more saline than the restoration site (Kruskal-Wallis; $p<0.05$ ), whereas salinities at Matochal and Huerta Tejada were generally comparable with those at the restoration site (Figs. 1a \& 1b; Kruskal-Wallis; $p>0.05)$. The mean annual hydroperiod varied in tandem at all sites from year to year (Friedman; $p<0.0001$ ) and was clearly related to the rainfall totals, particularly for autumn and winter, with longer flooding in the wetter years (Figs. 1c \& 1d). Cangrejo, Entremuros and Reserva Guadiamar generally experienced much longer flooding than the restoration site (Kruskal-Wallis; $p<0.05$ ), in contrast to Matochal and Huerta Tejada, which were generally more similar in flooding regime to it (Kruskal-Wallis; $p>0.05$ ). Within the restoration area, the lower-lying Travieso experienced generally longer flooding and greater salinities than the main area of Caracoles (Kruskal-Wallis; $p<0.05$ ).

\section{Vegetation}

\section{Spatial variation}

The structural matrix of perennial vegetation included 16 species across all reference sites in the seven-year period of study. Cluster analysis (Table 1a) yielded four main species assemblages that were highly significant (global R, one-way ANOSIM, 0.702, $p<0.0001$ ). The most frequent assemblage was strongly dominated by Arthrocnemum macrostachyum. 
The second most abundant was also dominated by A. macrostachyum, in association with Juncus subulatus and Bolboschoenus maritimus ('Arthrocnemum with helophytes'). A third was strongly dominated by Suaeda vera. The least abundant assemblage was nearly monospecific with Schoenoplectus litoralis. These perennial assemblages were represented differently at the five reference sites (Fig. 2). Only Cangrejo and Reserva Guadiamar supported the S. litoralis community; these sites, along with Entremuros, also had the only significant areas devoid of perennial vegetation. Most of the samples representing the $S$. vera community were found at Matochal or Huerta Tejada.

The data for the reference sites collectively showed that the areas occupied by the perennial assemblages could be differentiated by their local environmental conditions. The best model obtained from BIO-ENV analysis for the perennial species, using the 90 samples that included any perennial species, included four environmental variables: elevation, surface E.C., subsurface $\mathrm{pH}$ and summer hydroperiod $(\rho=0.502, p<0.001)$. The Schoenoplectus litoralis assemblage was found consistently at the lowest elevations, where it experienced prolonged flooding and relatively high surface salinities. The Arthrocnemum with helophytes, Arthrocnemum and Suaeda assemblages occupied successively higher ranges of local elevation, with concomitantly shorter flooding periods, and all experienced significantly lower surface salinities (E.C.) than the S. litoralis or bare areas (Fig. 3). Neither surface nor subsurface $\mathrm{pH}$ varied significantly between communities when tested separately (Figs. 3e \& 3f). However, subsurface $\mathrm{pH}$ was the last variable to be entered into the BIO-ENV model and only resulted in a slight increase in $\rho$.

The 69 annual and ephemeral species were clustered into seven assemblages (Table 1b) with a highly significant global R (one-way ANOSIM, 0.5694, $p<0.001$ ). The most frequent assemblage was characterized by Plantago coronopus, Leontodon longirostris, Polypogon maritimus and Plantago lanceolata. Polypogon maritimus was the dominant 
species in the second most abundant assemblage, followed by an assemblage clearly dominated by Medicago polymorpha. Three other assemblages with considerably lower frequency were dominated by Damasonium alisma, Lolium rigidum and Hordeum marinum, respectively. The final assemblage comprised Salsola soda and Salicornia ramosissima coexisting at low abundance.

BIO-ENV analysis of the annual species, using the 80 samples containing any annual species, identified the most significant subset of environmental factors associated with their community structure. The best model included four environmental variables, including two in common with that for the perennial species: elevation, surface E.C., winter hydroperiod and spring hydroperiod $(\rho=0.617, p<0.001)$.

Some but not all of the annual assemblages were associated with particular perennial ones (Table 2). The S. litoralis community generally lacked annual species, and areas devoid of perennials also tended to lack annuals. The most diverse annual assemblage, dominated by P. coronopus and L. longirostris was strongly associated with the Suaeda perennial assemblage. The Medicago-dominated annual assemblage was associated particularly with Arthrocnemum perennial assemblage. A wider range of annual assemblages was associated with the assemblage dominated by Arthrocnemum with helophytes but the Polypogondominated one was the most prominent.

\section{Temporal variation}

As expected, perennial assemblages were relatively stable. Examination of year-toyear transitions of assemblage classification for individual sampling points showed that circa $80 \%$ remained the same (Table 3a). Annual assemblages were more labile, with considerable variation in year-to-year transition probability (Table 3b). Nevertheless, most of them were more likely to stay the same than change from year to year; exceptions were the Hordeum- 
dominated assemblage that was most likely to change to the Medicago-Leontodon one, and the Damasonium-dominated assemblage that typically evolved into the Polypogon-

\section{Damasonium one.}

Although there was year-to-year variation in assemblage type at any location, there was little evidence of successional or other directional change. Separate multivariate analyses of perennial and annual species composition by NMDS (Fig. 4) showed that the centroids for neither the assemblages nor the individual reference sites migrated systematically from year to year between 2004 and 2010 .

\section{Discussion}

In our study, the reference sites were selected mainly for proximity to and potential hydrological connectivity with the restoration site (Weishar et al. 2005), as well as for their relatively undisturbed history. Nevertheless, the sites differed in their ranges of elevation above sea level and therefore showed consistent differences in the hydrological and hydrochemical characteristics measured. Lower-lying sites exhibited longer annual hydroperiods, mainly depending on rainfall, with difference in elevation of about $80 \mathrm{~cm}$ resulting in a difference in annual inundation of up to 200 days. Furthermore higher salinities in the surface layer of soil resulted from evapotranspiration during the dry season and salts leaching from higher areas. Similar diversity in water-table levels among reference sites has also been reported recently in a study of forested wetland restoration (Johnson et al. 2014).

These underlying ecohydrological gradients were the rationale for examining the structure and composition of vegetation across all five reference sites in detail. Hierarchical cluster analysis of the relatively few, long-lived, shrubby perennials that comprised the structural matrix of the vegetation revealed four main assemblages. These four perennial assemblages were dominated by Suaeda vera, Arthrocnemum macrostachyum, A. 
macrostachyum with helophytes and Schoenoplectus litoralis, respectively, and broadly correspond with communities described previously by García-Viñas et al. (2005) for Doñana marshes. Seven physiognomically subordinate assemblages of 69 annual species were also identified independently. Although these were more variable, spatial analyses revealed associations between the annual assemblages and particular perennial assemblages. Such associations probably reflected environmental tolerances common to the two life histories but annuals might also have experienced differential effects of interference from perennials, or in such a severe environment facilitation by them. Arthrocnemum subterminale, a close relative of the most abundant species at our sites (Arthrocnemum macrostachyum) had both kinds of effect on winter annuals in the upper zones of a Californian salt marsh (Callaway 1994). Bare ground was a feature of the mosaic in our reference areas, and annual communities rarely occurred where there were no perennials, a result consistent with facilitation. NMDS ordinations displaying species-composition centroids for the cluster-analysis assemblages showed more coherent and consistent groupings than equivalent centroids for the sites. This supports the idea that differences in vegetation composition between sites were determined largely by hydrological factors (Johnson et al. 2014). A practical consequence is that the species assemblages derived collectively from the sites should provide a more precise basis for defining reference condition than any derived from individual sites.

The ordination results also characterized changes with time. Although the composition of perennial and annual species in both the sites and their assemblages fluctuated from year to year, there was little evidence of directional change over the seven years. Hence they could serve to define dynamic ranges of reference state, as suggested by Hiers et al. (2012), a quantitative approach that incorporates the full range of temporal and spatial variation such that restoration targets reflect ecological dynamics, rather than using a singular optimum state. Another approach to a dynamic reference state emerges from the annual 
transition probabilities between assemblage types at any sampling point. In our study perennial assemblages had high fidelity, as might be expected for long-lived plants but, nevertheless, with a dynamic element mainly dependent on inter-annual fluctuations in hydrology that was also evident in the NMDS ordinations.

As expected, the annual assemblages were more labile, with generally high probabilities of transition from one assemblage to another in the following year. Such changes in the distribution and composition of annual communities would be sensitive to inter-annual differences in hydroperiod as they are largely driven by seasonal fluctuations in rainfall. Rapid responses to changes in water level have been demonstrated in the composition of lake-shore vegetation, associated with annual draw-down of regulated rivers in China (Liu et al. 2006). Another parallel can be seen in the effects of inter-annual variation in rainfall on the abundance and elevational distribution of annual salt-marsh species in California (Callaway \& Sabraw 1994). In their study, changes seen in response to natural precipitation and experimental watering suggested that increased salinity and water stress affected lower elevational limits, and excess water the upper limits of halophyte communities. In general, however, populations of annual halophytes may recover rapidly after heavy mortality, because their soil seed banks and negatively density-dependent seed production confer high intrinsic rates of population growth (Jefferies et al. 1981).

More broadly, the environmental measurements were successful in identifying the hydrochemical drivers of vegetation composition. The hydrochemical influence was evident in the different ranges in elevation, annual hydroperiod and salinity shown by the perennial assemblages, and was confirmed by the significant correlates of the BIO-ENV analysis. The importance of water table level as a primary determinant of the distribution of vegetation has been demonstrated in other wetland restoration projects, notably by Stroh et al. (2013) who used sum exceedance values above or below threshold water-table levels to explain patterns 
in colonizing vegetation. Although the water supply is mainly from the catchment via river channels, the effects of elevation on these non-tidal marshes would be analogous to those on tidal marshes, where flooding results in soil anaerobiosis (and hence low redox potential, with toxic reduced ions) or exposure leads to water stress and increased salinity. These syndromes are widely recognised as determinants of species (Davy et al. 2011) and community (Mossman et al. 2012a, 2012b; Rupprecht et al. 2015) distribution. In our study, the key difference between tidal marshes and embanked sites was in the dominant periodicity of flooding, which is annual in this part of the Doñana marshlands, rather than semi-diurnal. The demonstrable importance of elevation (and hence hydroperiod) indicated the potential value of multiple reference sites for the restoration of Caracoles Estate. Although surface elevation at Caracoles varied by little more than $1 \mathrm{~m}$, it was apparent from the distributions and ranges of elevation that none of five encircling reference sites individually could replicate it topographically. However, collectively the reference sites were remarkably representative. Analysis of the underlying drivers of environmental heterogeneity (Weinstein et al. 2001) and change (Hiers et al. 2012) has been established as a rationale for the definition of reference vegetation. Hydroperiod is a driver that has been shown previously to differ between multiple reference sites and also to fluctuate from year to year within and among them (Barton et al. 2008). Consequently, it is likely that the reference sites collectively have the potential to represent an appropriate reference condition for purposes of vegetation restoration in coastal saline marshes. Broad community distributions might be predicted from average elevation: below $130 \mathrm{~cm}$ above sea level, the $S$. litoralis assemblage is likely to dominate; $130-155 \mathrm{~cm}$, the A. macrostachyum mixed assemblage; $155-182 \mathrm{~cm}$, the A. macrostachyum-dominated assemblage; and above $182 \mathrm{~cm}$, the $S$. vera assemblage. The interstitial annual assemblages are less predictable, but their associations with perennials could provide some insight into likely distribution. 
The Doñana National Park is a wetland of almost unrivalled conservation value in Europe (García-Novo \& Marín 2006) and the opportunity to restore a large area after previous conversion to agricultural use is important. Historical information had informed the reinstatement of the hydrological regime but provided little insight into prior vegetation. In any case, historical reference points may no longer represent the restoration potential of a site (Balaguer et al. 2014). Novel starting points, climatic unpredictability and environment heterogeneity can combine to engender considerable uncertainty about trajectories of change in the plant communities (Zedler \& Callaway 1999; Matthews \& Spyreas 2010). It has been argued that such circumstances demand 'open-ended' restoration, where 'natural processes are promoted, and with no specific reference system' (Hughes et al. 2012). However, the approach taken here, of systematically sampling multiple reference sites that collectively encompassed the spatio-temporal environmental heterogeneity of the restoration site, was designed to take account of the necessarily dynamic nature of reference condition (White \& Walker 1997). This is especially important for spatially and temporally highly dynamic ecosystems like saltmarshes. In particular, the use of LIDAR digital terrain modelling (Blott \& Pye 2004) and satellite imagery enabled prediction of hydroperiod within a narrow range of elevation. Such a hydrologically-based strategy could be applicable to the problems of vegetation restoration in other large heterogeneous wetlands (Hughes et al. 2011).

\section{Acknowledgements}

A.V.M. held a pre-doctoral fellowship, with three 3-month visits to the University of East Anglia, financed by the University of Huelva and the CEICAMBIO. We thank to the Remote Sensing and GIS Laboratory (LAST-EBD) of Doñana Biological Station for support with the differential GPS. We also thank Hannah Mossman, Alastair Grant, Andrés PérezVázquez, Alberto García-Álvarez and Adrián Ramos-Merchante for assistance with statistical 
analysis, and Kathrin Kiehl and three reviewers for many helpful suggestions. We are very grateful to all the partners, volunteers and practitioners who helped with field and laboratory work. This publication is a contribution from CEIMAR and also a contribution from CEICAMBIO.

\section{LITERATURE CITED}

Barton CD, Andrews DM, Kolka RK (2008) Evaluating hydroperiod response in restored Carolina Bay wetlands using soil physicochemical properties. Restoration Ecology $16: 668-677$

Balaguer L, Escudero A, Martín-Duque JF, Mola I, Aronson J (2014) The historical reference in restoration ecology: re-defining a cornerstone concept. Biological Conservation $176: 12-120$

Blott SJ, Pye K (2004) Application of Lidar digital terrain modelling to predict intertidal habitat development at a managed retreat site: Abbotts Hall, Essex, UK. Earth Surface Processes and Landforms 29:893-905

Callaway RM (1994) Facilitative and interfering effects of Arthrocnemum subterminale on winter annuals. Ecology 75:681-686

Callaway RM, Sabraw CS (1994) Effects of variable precipitation on the structure and diversity of a California salt marsh community. Journal of Vegetation Science 5:433438

Clarke KR, Ainsworth M (1993) A method of linking multivariate community structure to environmental variables. Marine Ecology Progress Series 92:205-219

Clarke KR, Warwick RM (1994) Change in marine communities: an approach to statistical analysis and interpretation. Natural Environment Research Council, Plymouth, UK. 
Clewell AF, Aronson J (2007) Ecological restoration: principles, values, and structure of an emerging profession. Society for Ecological Restoration \& Island Press, Washington, U.S.A.

Davy AJ, Brown MJ, Mossman HL, Grant A (2011) Colonization of a newly developing salt marsh: disentangling independent effects of elevation and redox potential on halophytes. Journal of Ecology 99:1350-1357

Díaz-Delgado R, Bustamante J, Pacios F, Aragonés D (2006) Hydroperiod of Doñana marshes: natural or anthropic origin of inundation regime? In Proceedings of the $1^{\text {st }}$ Global Wetland Symposium, Frascati, Italy. ESA \& Ramsar Convention

Díaz-Delgado R, Aragonés D, Ameztoy I, Bustamante J (2010) Monitoring marsh dynamics through remote sensing. Pages 375-386. In: Hurford C, Schneider M, Cowx I (eds) Conservation monitoring in freshwater habitats: a practical guide and case studies. Springer, Dordrecht, Netherlands

Espinar JL (2009) 1410 Pastizales salinos mediterráneos (Juncetalia maritimi). In: Bases ecológicas preliminares para la conservación de los tipos de hábitat de interés comunitario en España. Ministerio de Medio Ambiente, y Medio Rural y Marino, Madrid, Spain

Garbutt A, Wolters M (2008) The natural regeneration of salt marsh on formerly reclaimed land. Applied Vegetation Science 11:335-344

García LV, Clemente L, Marañón T, Moreno A (1993) Above-ground biomass and species richness in a Mediterranean salt marsh. Journal of Vegetation Science 4:417-424

García-Novo F, Marín C (2006) Doñana: water and biosphere. Doñana 2005, Confederación Hidrográfica del Guadalquivir, Ministerio Medio Ambiente, Madrid. Spain 
García-Viñas JI, Mintegui JA, Robredo JC (2005) La vegetación en la marisma del Parque Nacional de Doñana en relación a su régimen hidráulico. Organismo Autónomo de Parques Nacionales, Ministerio de Medio Ambiente, Madrid, Spain

Hammer Ø, Harper DAT, Ryan PD (2001) PAST: paleontological statistics software package for education and data analysis. Palaeontologia Electronica 4:1-9

Hiers JK, Mitchell RJ, Barnett A, Walters JR, Mack M, Williams B, Sutter R (2012) The dynamic reference concept: measuring restoration success in a rapidly changing noanalogue future. Ecological Restoration 30:27-36

Hughes FM, Stroh PA, Adams WM, Kirby KJ, Mountford JO, Warrington S (2011) Monitoring and evaluating large-scale, 'open-ended' habitat creation projects: A journey rather than a destination. Journal for Nature Conservation 19:245-253

Hughes FM, Adams WM, Stroh PA (2012) When is open-endedness desirable in restoration projects? Restoration Ecology 20:291-295

IBM Corp. (2012) IBM SPSS Statistics for Windows, Version 21.0. Armonk, New York: IBM Corp.

Jefferies RL, Davy AJ, Rudmik T (1981) Population biology of the salt marsh annual Salicornia europaea agg. Journal of Ecology 69:17-31

Johnson YB, Shear TH, James AL (2014) Novel ways to assess forested wetland restoration in North Carolina using ecohydrological patterns from reference sites. Ecohydrology $7: 692-702$

Liu GH, Li W, Zhou J, Liu WZ, Yang D, Davy AJ (2006) How does the propagule bank contribute to cyclic vegetation change in a lakeshore marsh with seasonal drawdown? Aquatic Botany 84:137-143 
Marañón T, García LV, Murillo JM, Clemente L (1989) Las marismas del Guadalquivir, reserva biogenética de plantas tolerantes a la salinidad. Anales de Edafología y Agrobiología 48:725-740

Matthews JW, Spyreas G (2010) Convergence and divergence in plant community trajectories as a framework for monitoring wetland restoration progress. Journal of Applied Ecology 47:1128-1136

Mitsch WJ, Gosselink JG (1993) Wetlands. Van Nostrand Reinhold, New York, U.S.A.

Mossman HL, Davy AJ, Grant A (2012a) Does managed coastal realignment create saltmarshes with 'equivalent biological characteristics' to natural reference sites? Journal of Applied Ecology 49:1446-1456

Mossman HL, Brown MJ, Davy AJ, Grant A (2012b) Constraints on salt marsh development following managed coastal realignment: dispersal limitation or environmental tolerance? Restoration Ecology 20:65-75

Onaindia M, Albizu I, Amezaga I (2001) Effect of time on the natural regeneration of salt marsh. Applied Vegetation Science 4:247-256

R Core Team (2013) R: A language and environment for statistical computing. R Foundation for Statistical Computing, Vienna, Austria. URL: http://www.R-project.org/

Rivas-Martínez S, Costa M, Castroviejo S, Valdés E (1980) Vegetación de Doñana (Huelva, España). Lazaroa 2:5-189

Rupprecht F, Wanner A, Stock M, Jensen K (2015) Succession in salt marshes - large-scale and long-term patterns after abandonment of grazing and drainage. Applied Vegetation Science 18:86-98

Saura J, Bayán B, Casas J, Ruíz de Larramendi A, Urdiales C (2001) Documento marco para el desarrollo del Proyecto Doñana 2005. Ministerio de Medio Ambiente, Madrid, Spain 
Stroh PA, Mountford JO, Araya YN, Hughes FMR (2013) Quantifying soil hydrology to explain the development of vegetation at an ex-arable wetland restoration site. Wetlands 33:311-32

Van Loon-Steensma JM, Van Dobben HF, Slim PA, Huiskes HPJ, Dirkse GM (2015) Does vegetation in restored salt marshes equal naturally developed vegetation? Applied Vegetation Science 18:674-682

Weinstein MP, Teal JM, Balletto JH, Strait KA (2001) Restoration principles emerging from one of the world's largest tidal marsh restoration projects. Wetlands Ecology and Management 9:387-407

Weishar LL, Teal JM, Hinkle R (2005) Designing large-scale wetland restoration for Delaware Bay. Ecological Engineering 25:231-239

White PS, Walker JL (1997) Approximating nature's variation: selecting and using reference information in restoration ecology. Restoration Ecology 5:338-349

Zedler JB, Callaway RC (1999) Tracking wetland restoration: do mitigation sites follow desired trajectories? Restoration Ecology 7:69-73 


\section{Supporting information}

The following information may be found in the online version of this article:

Figure S1. Location of the study sites within the Guadalquivir Marshes of the Doñana National Park.

Figure S2. Distribution of elevational range of the sampling points in the restoration and candidate reference sites. 
Table 1. Relative frequency and mean cover (in parentheses) of species present in the clusters identified at the reference sites. (a) Perennial and (b) annual assemblages. Species are ordered by their weight in the SIMPER analysis (only the 20 most important annuals are shown). The dominant species in each cluster are in bold. Asterisks indicate less than $1 \%$ cover. Key to assemblage names: perennial assemblages (a) dominated by (SL) Schoenoplectus litoralis, (AH) Arthrocnemum macrostachyum with helophytes, (AM) Arthrocnemum macrostachyum, (SV) Suaeda vera and (NP) no perennials. Annual assemblages (b) dominated by (HM) Hordeum marinum, (DA) Damasonium alisma, (PM) Polypogon maritimus, (MP) Medicago polymorpha, (SS) Salicornia ramosissima and Salsola soda, (PC) Plantago coronopus, (LR) Lolium rigidum and (NA) no annuals.

(a)

\begin{tabular}{|c|c|c|c|c|c|c|c|c|}
\hline \multirow[b]{3}{*}{ Arthrocnemum macrostachyum } & \multicolumn{8}{|c|}{ Cluster } \\
\hline & \multicolumn{2}{|c|}{ SL } & \multicolumn{2}{|c|}{$\mathrm{AH}$} & \multicolumn{2}{|c|}{ AM } & \multicolumn{2}{|c|}{ SV } \\
\hline & & r & 87 & (12) & 100 & (27) & 60 & $(4)$ \\
\hline Suaeda vera & & . & 2 & * & 3 & * & 100 & $(21)$ \\
\hline Juncus subulatus & & . & 55 & (4) & 9 & * & 2 & x \\
\hline Bolboschoenus maritimus & 2 & * & 48 & (2) & 1 & * & 3 & \\
\hline Schoenoplectus litoralis & 100 & (18) & 2 & * & . & . & . & \\
\hline Sarcocornia perennis ssp. perennis & & . & 19 & (1) & 1 & * & 5 & \\
\hline Phragmites australis & . & . & 8 & * & . & . & . & \\
\hline Polygonum equisetiforme & . & . & 4 & * & . & . & 1 & \\
\hline Aeluropus littoralis & . & . & 4 & * & . & . & . & \\
\hline Rumex pulcher ssp. Divaricatus & . & . & . & . & $<1$ & * & 2 & \\
\hline Frankenia laevis & . & . & . & . & . & . & 3 & \\
\hline Tamarix canariensis & & . & 1 & * & . & . & . & \\
\hline Spartina densiflora & . & . & 1 & * & . & . & . & \\
\hline Inula crithmoides & . & . & $<1$ & * & . & . & . & \\
\hline Allium cf. ampeloprasum & & . & . & . & $<1$ & * & 2 & \\
\hline Oenanthe fistulosa & - & . & $<1$ & * & . & . & . & \\
\hline Frequency & 43 & & 310 & & 450 & & 139 & \\
\hline
\end{tabular}

(b)

\begin{tabular}{|c|c|c|c|c|c|c|c|c|c|c|c|c|c|c|}
\hline \multirow[b]{3}{*}{ Damasonium alisma } & \multicolumn{14}{|c|}{ Cluster } \\
\hline & \multicolumn{2}{|c|}{$\mathrm{HM}$} & \multicolumn{2}{|c|}{ DA } & \multicolumn{2}{|c|}{ PM } & \multicolumn{2}{|c|}{ MP } & \multicolumn{2}{|c|}{ SS } & \multicolumn{2}{|c|}{ PC } & \multicolumn{2}{|c|}{ LR } \\
\hline & 9 & * & 100 & (37) & 72 & (3) & 3 & * & . & . & 6 & * & $\cdot$ & \\
\hline Medicago cf. polymorpha & 52 & (1) & . & . & 11 & * & 96 & (20) & . & . & 39 & * & 66 & (6) \\
\hline Leontodon longirostris & 78 & (1) & . & . & 42 & (1) & 87 & (6) & . & . & 72 & (4) & 76 & (7) \\
\hline Plantago coronopus & 36 & * & 1 & * & 28 & * & 73 & (3) & 7 & * & 91 & (7) & 36 & * \\
\hline Polypogon maritimus ssp. maritimus & 17 & * & 8 & * & 78 & (5) & 77 & (3) & 2 & * & 66 & (3) & 19 & * \\
\hline Hordeum cf. marinum & 100 & (13) & 5 & * & 24 & * & 73 & (2) & . & . & 42 & * & 78 & (4) \\
\hline Rumex dentatus ssp. Halacsyi & 56 & * & 33 & * & 78 & (3) & 88 & (3) & . & . & 48 & * & 48 & * \\
\hline Lolium cf. rigidum & 3 & * & . & . & 6 & * & 7 & * & . & . & 43 & (1) & 100 & (48) \\
\hline Lythrum cf. tribracteatum & 8 & * & 78 & (4) & 60 & (2) & 13 & * & 2 & * & 17 & * & 6 & * \\
\hline Beta macrocarpa & 61 & (1) & 2 & * & 15 & * & 88 & (4) & 2 & * & 32 & * & 27 & * \\
\hline Plantago lanceolata & 11 & * & . & . & 11 & * & 27 & * & . & . & 63 & (3) & 66 & (3) \\
\hline Juncus bufonius & 13 & * & . & . & 29 & * & 72 & (2) & . & . & 43 & (1) & 10 & * \\
\hline Phalaris cf. minor & 14 & * & 1 & * & 19 & * & 43 & * & . & . & 47 & (2) & 34 & * \\
\hline Parapholis pycnantha & 5 & * & 2 & * & 27 & * & 54 & (2) & . & . & 34 & * & 19 & * \\
\hline
\end{tabular}




\begin{tabular}{|c|c|c|c|c|c|c|c|c|c|c|c|c|c|}
\hline Chamaemelum mixtum & & & & & 16 & * & 72 & (4) & . & . & 20 & * & 1 \\
\hline Spergularia cf. nicaeensis & 9 & * & 1 & * & 40 & * & 82 & (2) & 2 & * & 29 & * & 9 \\
\hline Coronopus squamatus & 31 & * & 7 & * & 44 & * & 52 & * & 2 & * & 19 & * & 6 \\
\hline Salsola soda & 2 & * & 8 & * & 9 & * & . & . & 98 & (3) & 16 & * & 3 \\
\hline Salicornia ramosissima & . & . & r. & . & 4 & * & 1 & * & 61 & (3) & 8 & * & . \\
\hline Bromus cf. lanceolatus & . & . & . & . & 2 & * & 3 & * & . & . & 33 & (1) & 27 \\
\hline Frequency & 64 & & 83 & & 192 & & 181 & & 46 & & 265 & & 67 \\
\hline
\end{tabular}


Table 2. The fraction of annual assemblages associated with each perennial assemblage. Data for individual sampling points were aggregated for the five reference sites from 2004-2010. Association between perennial and annual assemblages: $\chi^{2}=1246.5, d f=28, p<0.0001$. The greatest fraction in each row is in bold. Marginal and total frequencies are also shown. For key to assemblage names see Table 1.

\begin{tabular}{|c|c|c|c|c|c|c|c|c|c|c|}
\hline \multirow{2}{*}{\multicolumn{2}{|c|}{ Assemblage }} & \multicolumn{8}{|c|}{ Annuals } & \multirow{3}{*}{$\begin{array}{r}\text { Frequency } \\
43\end{array}$} \\
\hline & & \multirow{2}{*}{$\begin{array}{c}\mathrm{HM} \\
0\end{array}$} & \multirow{2}{*}{$\begin{array}{c}\text { DA } \\
0\end{array}$} & \multirow{2}{*}{$\begin{array}{c}\text { PM } \\
0\end{array}$} & \multirow{2}{*}{$\begin{array}{c}\text { MP } \\
0\end{array}$} & \multirow{2}{*}{$\begin{array}{c}\text { SS } \\
0.233\end{array}$} & \multirow{2}{*}{$\begin{array}{c}\mathrm{PC} \\
0\end{array}$} & \multirow{2}{*}{$\begin{array}{c}\text { LR } \\
0.000\end{array}$} & \multirow{2}{*}{$\begin{array}{c}\text { NA } \\
0.767\end{array}$} & \\
\hline \multirow{6}{*}{ Perennials } & $\mathrm{SL}$ & & & & & & & & & \\
\hline & $\mathrm{AH}$ & 0.006 & 0.223 & 0.332 & 0.045 & 0.042 & 0.181 & 0.081 & 0.090 & 310 \\
\hline & AM & 0.122 & 0.031 & 0.173 & 0.360 & 0.002 & 0.222 & 0.069 & 0.020 & 450 \\
\hline & SV & 0.043 & 0 & 0.065 & 0.029 & 0 & 0.777 & 0.079 & 0.007 & 139 \\
\hline & NP & 0.008 & 0 & 0.016 & 0.008 & 0.171 & 0.008 & 0 & 0.791 & 129 \\
\hline & Frequency & 64 & 83 & 192 & 181 & 46 & 265 & 67 & 173 & 1071 \\
\hline
\end{tabular}


Table 3. Transition matrices for (a) perennial and (b) annual assemblages over the whole study period. Values indicate the probability of changing from an assemblage at year $\mathrm{n}$ to one at year $n+1$. Values in bold indicate the probability of an assemblage not changing. Marginal and total frequencies are also shown. For key to assemblage names see Table 1.

(a)

\begin{tabular}{|c|c|c|c|c|c|c|c|}
\hline & \multirow[b]{2}{*}{ Assemblage } & \multicolumn{5}{|c|}{ Year $n+1$} & \multirow[b]{2}{*}{ Frequency } \\
\hline & & NP & SL & $\mathrm{AH}$ & AM & SV & \\
\hline & NP & 0.777 & 0.089 & 0.107 & 0.027 & 0 & 112 \\
\hline & SL & 0.206 & 0.794 & 0 & 0 & 0 & 34 \\
\hline \multirow[t]{4}{*}{ Year $n$} & $\mathrm{AH}$ & 0.032 & 0.014 & 0.807 & 0.147 & 0 & 218 \\
\hline & AM & 0.002 & 0 & 0.227 & 0.744 & 0.026 & 418 \\
\hline & SV & 0 & 0 & 0.017 & 0.085 & 0.898 & 118 \\
\hline & Frequency & 102 & 40 & 285 & 356 & 117 & 900 \\
\hline
\end{tabular}

(b)

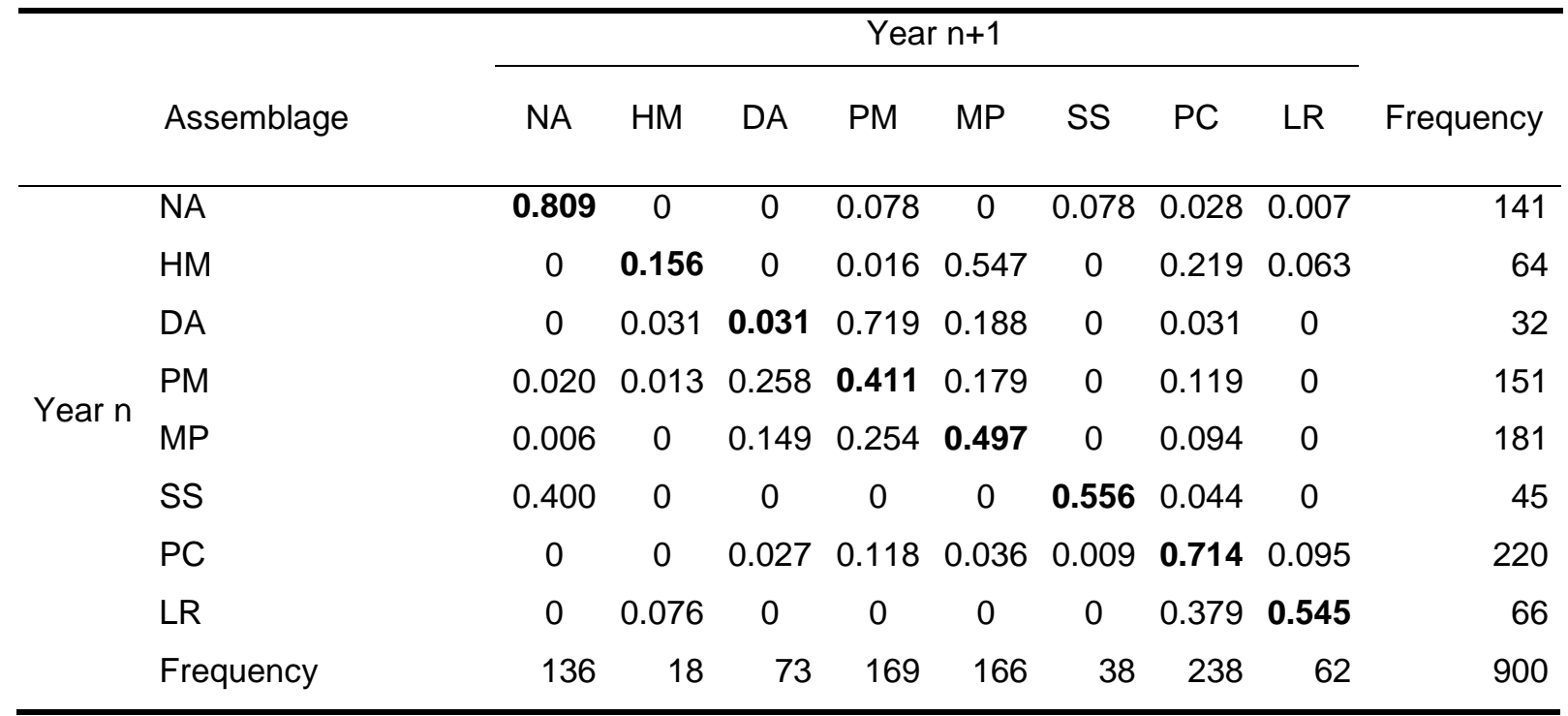




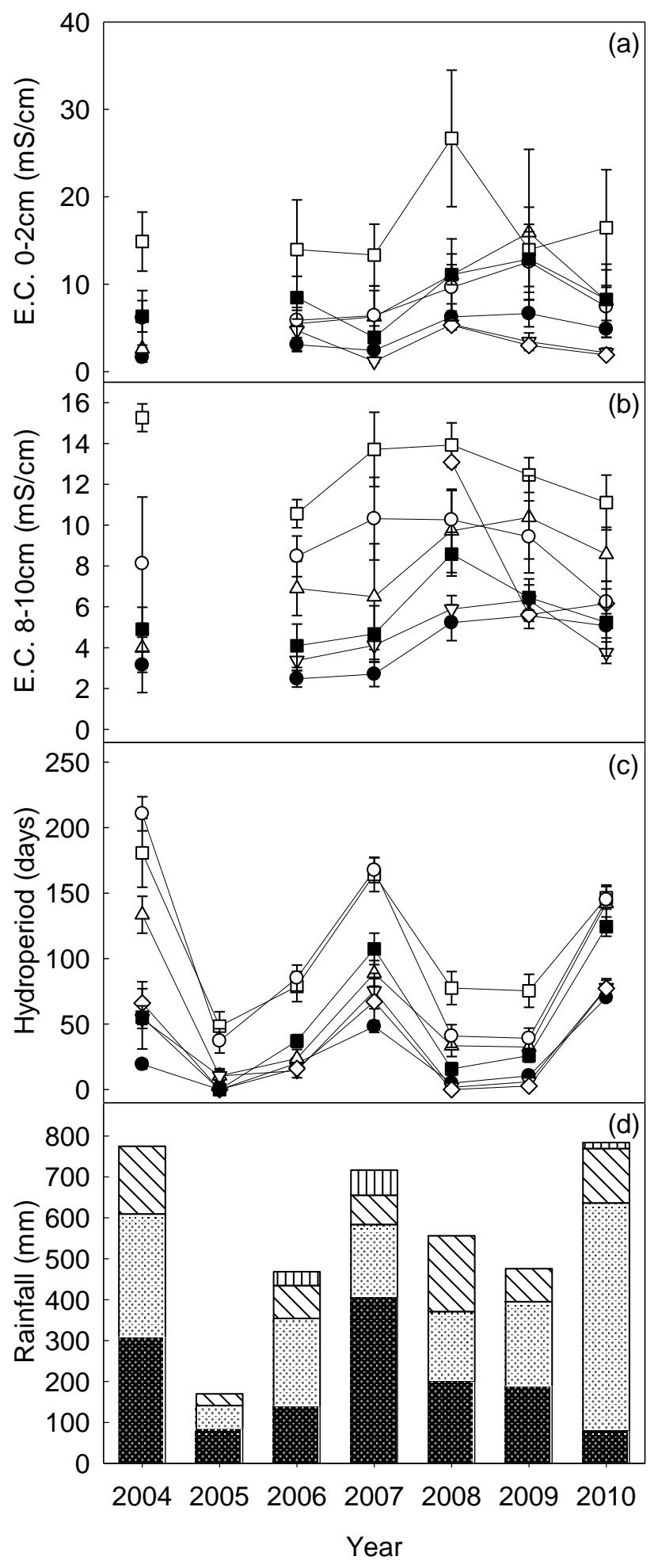

Figure 1. Annual variation in salinity (electrical conductivity) in surface (E.C. 0-2) and subsurface (E.C. 8-10) soils, annual hydroperiod and seasonal rainfall. Restoration sites: Caracoles (main area), $\square$ Travieso. Reference sites: $\square$ Cangrejo, $\triangle$ Entremuros, $\nabla$ Huerta Tejada, $\diamond$ Matochal and $\odot$ Reserva Guadiamar. Error bars represent \pm SE. Rainfall: Autumn, $\square$ Winter, $\mathbf{s}$ Spring and $\amalg$ Summer. 


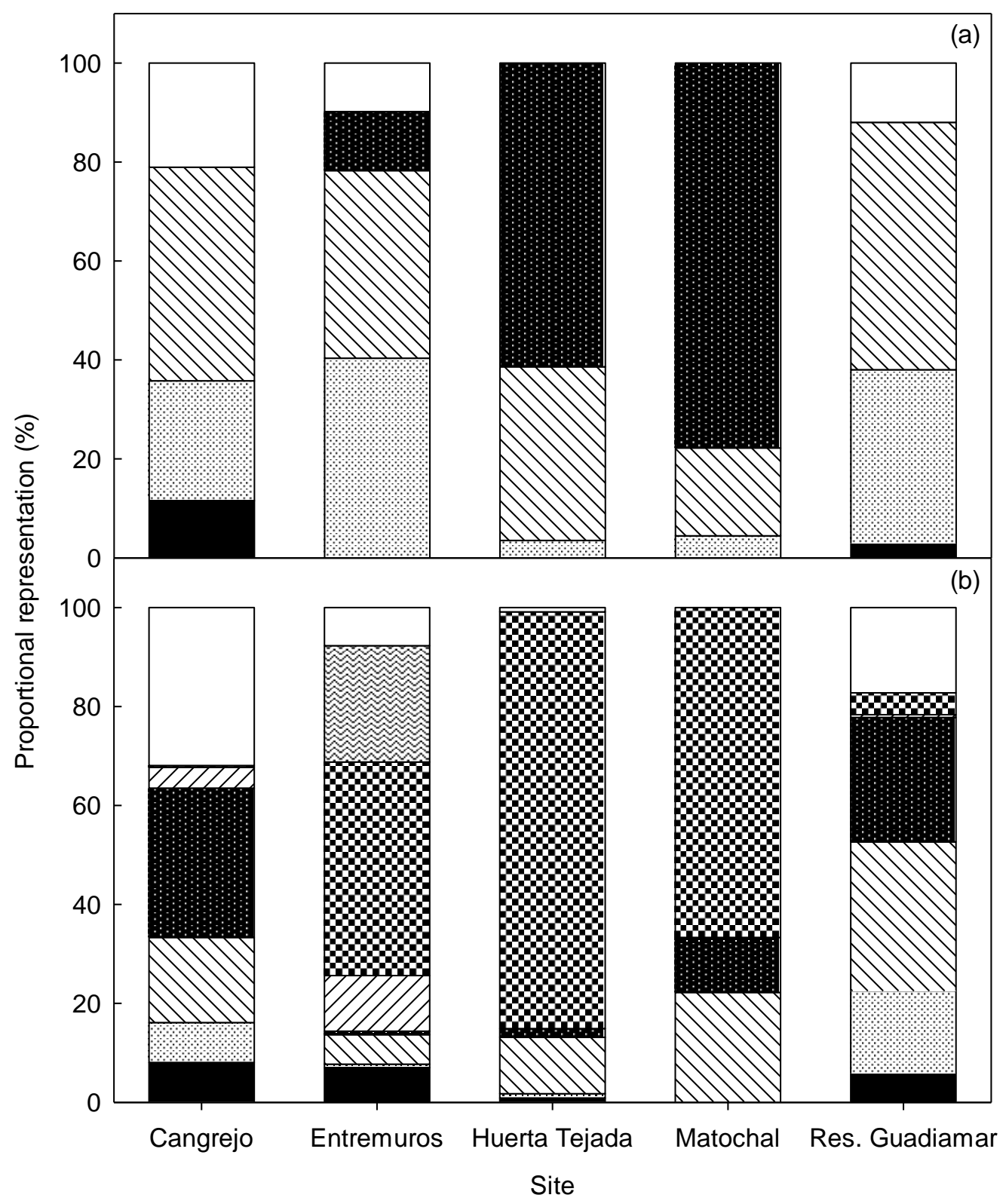

Figure 2. The proportional distribution of (a) perennial and (b) annual assemblages at the five reference sites. Perennial assemblages dominated by: Schoenoplectus litoralis, Arthrocnemum macrostachyum with helophytes, 图 Arthrocnemum macrostachyum, Suaeda vera and $\square$ no perennials. Annual assemblages dominated by: $\mathbf{\square}$ Hordeum marinum, [Damasonium alisma, 圈 Polypogon maritimus, : Medicago polymorpha, Salicornia ramosissima and Salsola soda, $\mathbf{0}$ Plantago coronopus, 2 Lolium rigidum and $\square$ no annuals. See Table 1 for details of assemblages. 


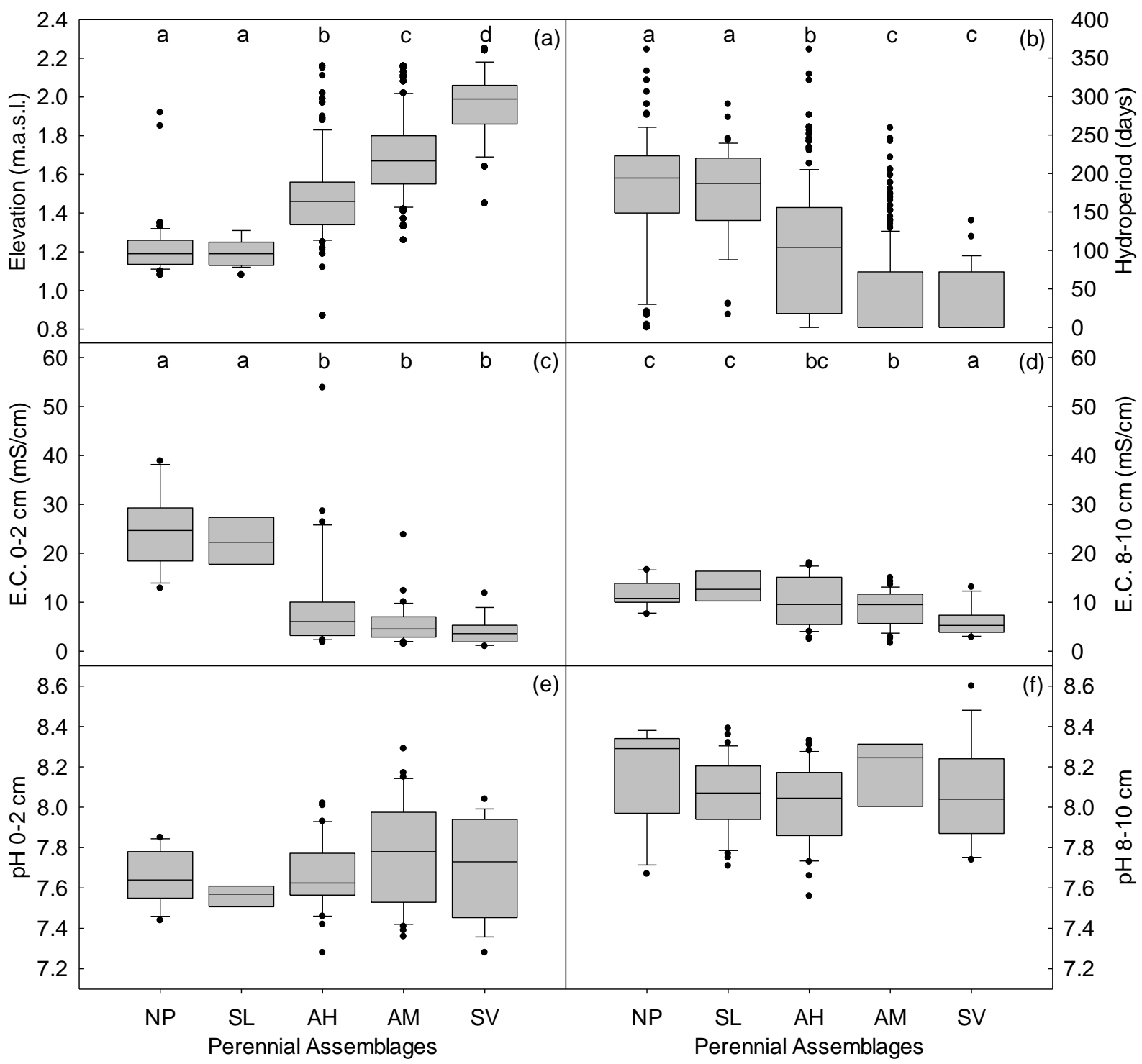

Figure 3. Boxplots of values of (a) elevation, (b) annual hydroperiod, (c) surface salinity (E.C. 0-2 cm), (d) subsurface salinity (E.C. $8-10 \mathrm{~cm}$ depth), (e) surface $\mathrm{pH}$ and (f) subsurface $\mathrm{pH}$ associated with the four perennial assemblages. Assemblages dominated by: no perennials (NP), Schoenoplectus litoralis (SL), Arthrocnemum macrostachyum with helophytes (AH), Arthrocnemum macrostachyum (AM) and Suaeda vera (SV). Bars not sharing the same letters are significantly different $(p<0.05$; Kruskal-Wallis test for elevation, hydroperiod and $\mathrm{EC}$; ANOVA for $\mathrm{pH})$. 


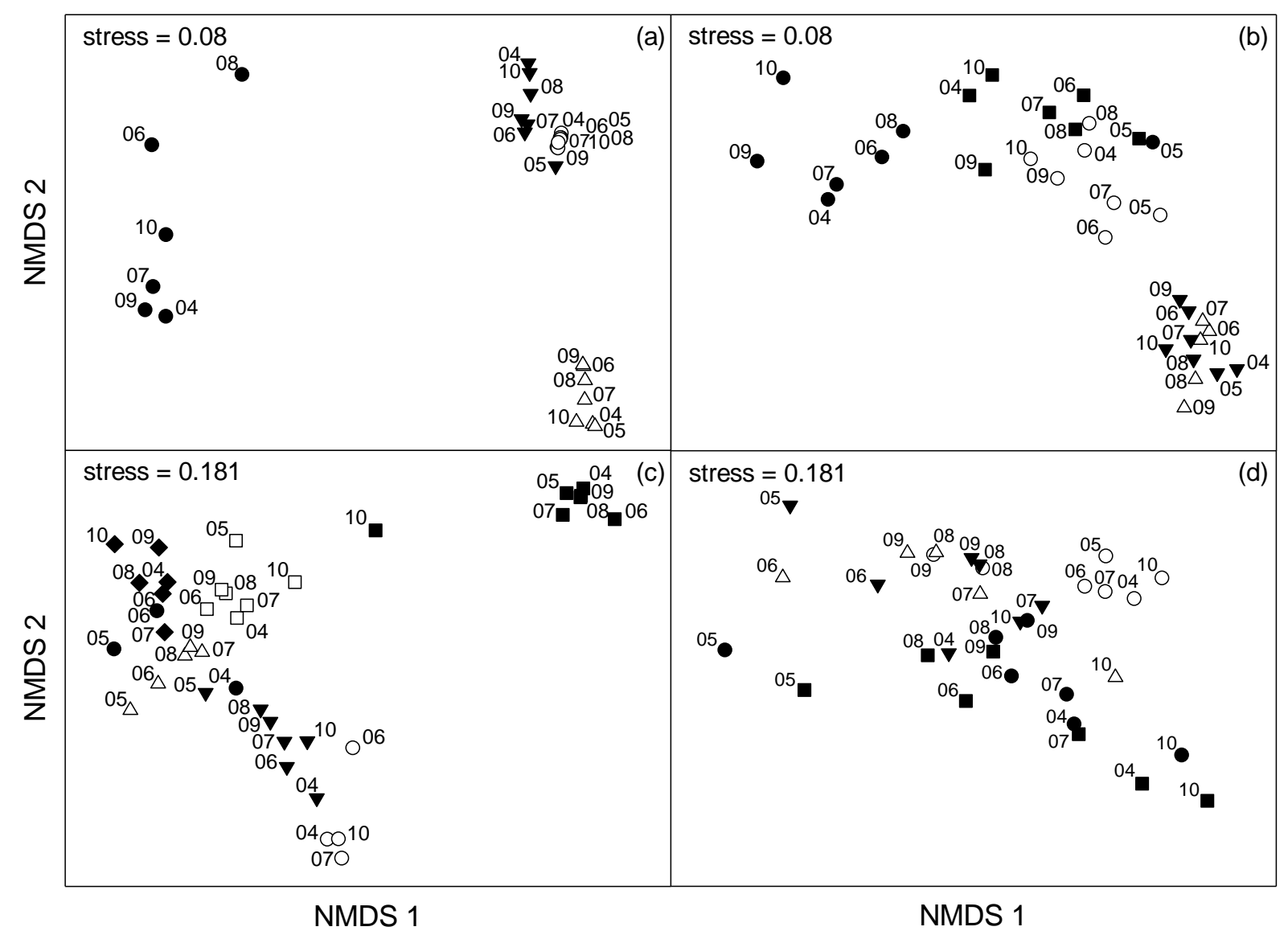

Figure 4. NMDS based on the perennial and annual species separately: (a) 27 centroids resulting from combinations of four perennial assemblages and seven years (assemblage 1 not represented in 2005); (b) 33 centroids resulting from combinations of five reference sites and seven years based on perennials (Matochal was not sampled in 2004 and 2005); (c) 39 centroids resulting from combinations of seven annual assemblages and seven years (some assemblages were not represented certain years); (d) 33 centroids resulting from combinations of five reference sites and seven years based on annuals. Key to assemblages dominated by perennials (a): • Schoenoplectus litoralis, ○ Arthrocnemum macrostachyum, $\mathbf{\nabla}$ Arthrocnemum macrostachyum with helophytes and $\triangle$ Suaeda vera. Key to assemblages dominated by annuals (c): • Hordeum marinum, o Damasonium alisma, $\mathbf{\nabla}$ Polypogon maritimus, $\triangle$ Medicago sp., - Salicornia ramosissima and Salsola soda, $\square$ Plantago coronopus and $\bullet$ Lolium rigidum. Key to reference sites (b, d): • Cangrejo, ○ Entremuros, $\boldsymbol{\nabla}$ Huerta Tejada, $\triangle$ Matochal and - Reserva Guadiamar. Years 2004-2010 are indicated by 0410. 


\section{Supporting information}

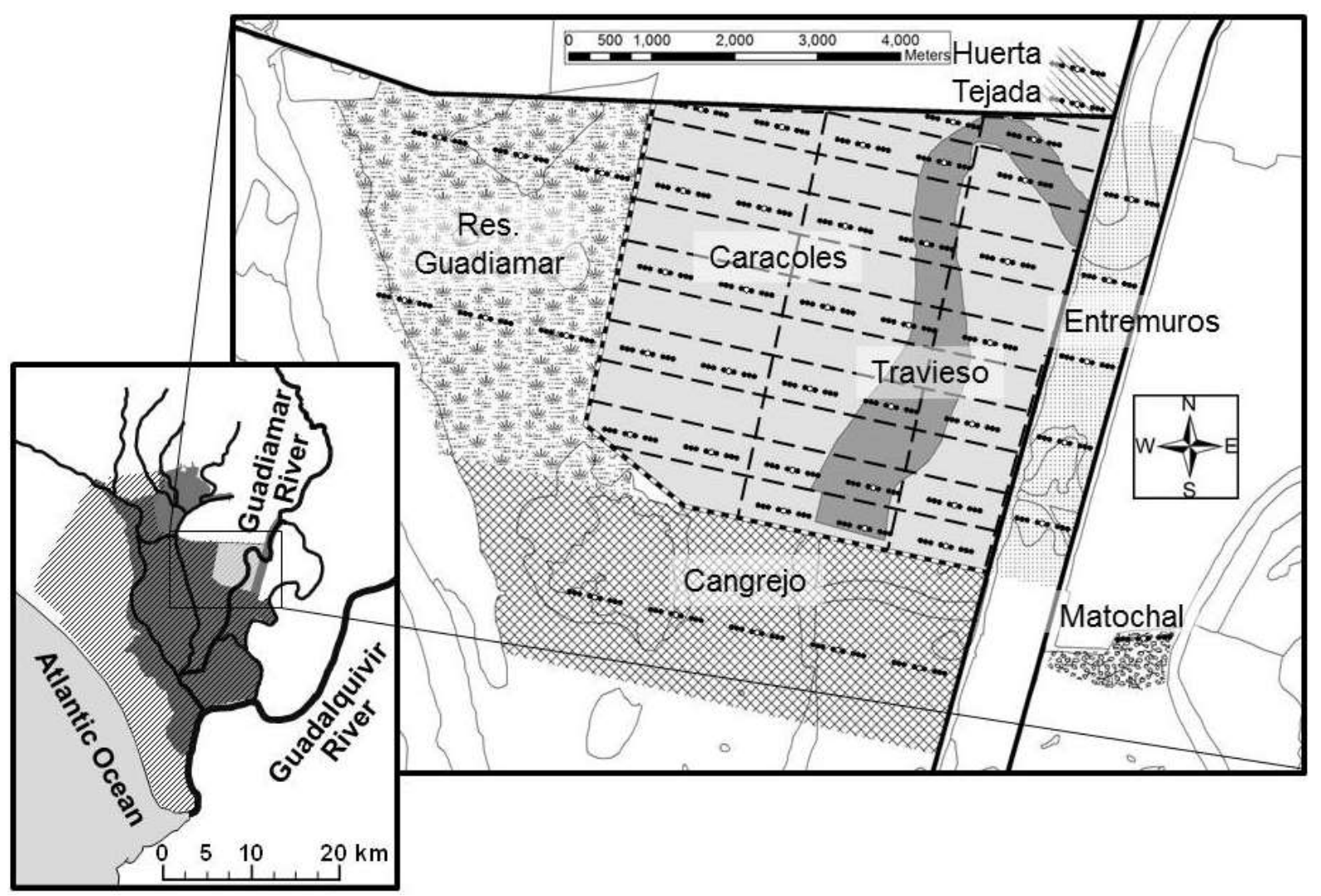

Figure S1. Location of the study sites within the Guadalquivir Marshes (dark shading, inset) of the Doñana National Park (hatched area, inset). Reference sites (Cangrejo, Reserva Guadiamar, Huerta Tejada, Entremuros and Matochal) are shown surrounding the designated restoration sites (Caracoles, and the re-excavated Travieso channel). Sampling was carried out along transects: $\bullet$ permanent sampling points; $\bigcirc$ subset of soil-sampling points.

Restoration actions: - - - blocked drainage ditches across Caracoles; $\ldots$ embankments that have been removed; remaining embankments. 


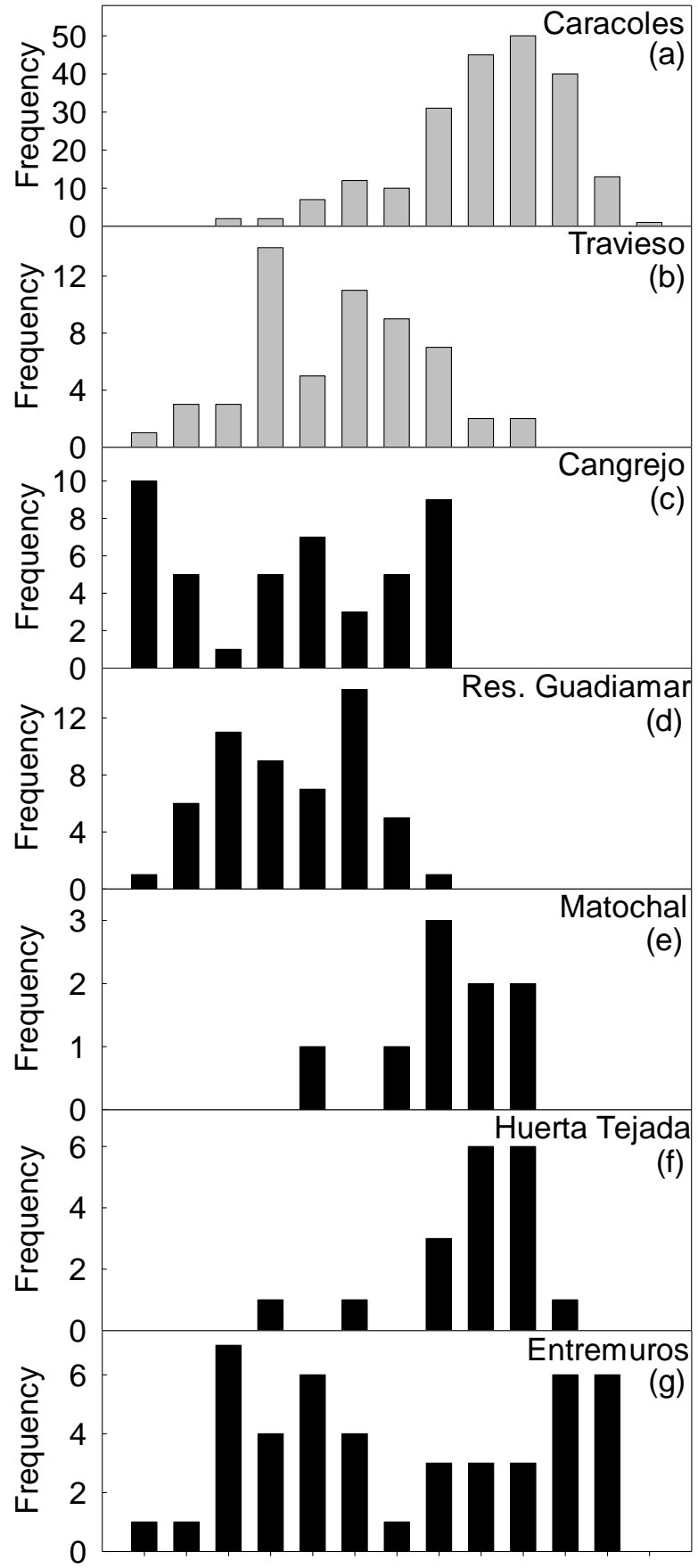

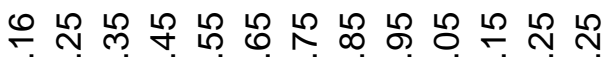

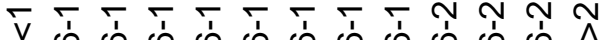
ق

\section{Elevation (m.a.s.I.)}

Figure S2. Distribution of elevational range of the sampling points in the $\square$ restoration and candidate reference sites. Restoration sites: (a) Caracoles (main area) and (b) Travieso (after re-excavation in 2004). Reference sites: (c) Cangrejo, (d) Reserva Guadiamar, (e) Matochal, (f) Huerta Tejada and (g) Entremuros. 